\title{
PENGARUH MODEL PEMBELAJARAN PROBLEM BASED LEARNING TEHADAP PEMAHAMAN KONSEP SISWA PADA TEMA 7 INDAHNYA KERAGAMAN DI NEGERIKU KELAS IV SDN 26 KENDARI
}

\author{
Febrianty Shintya ${ }^{1)}$, Lisnawati Rusmin ${ }^{1)}$, La Ode Safiun Arihi ${ }^{1)}$ \\ 1) Jurusan Pendidikan Guru Sekolah Dasar, \\ FKIP Universitas Halu Oleo \\ Email: shintyafebrianty046@gmail.com, lisnawatirusmin0@gmail.com
}

\begin{abstract}
Abstrak: Penelitian ini menggunakan metode pre eksperimen dengan desain penelitian The Non Equivalent Posttest Control Group Design. Populasi dalam penelitian ini adalah seluruh siswa kelas IV SD Negeri 26 Kendari tahun ajaran 2018/2019 yang terdiri dua kelas IV.A dan IV.B. Sampel dalam penelitian ini adalah siswa kelas IV.A SD Negeri 26 Kendari yang berjumlah 21 siswa. Teknik pengumpulan data dilakukan dengan metode tes, wawancara dan observasi. Teknik analisis data menggunakan analisis deskriptif dan analisis inferensial. Berdasarkan hasil analisis data dan pembahasan diperoleh kesimpulan bahwa model pembelajaran Problem Based Learning (PBL) memberikan pengaruh yang signifikan terhadap pemahaman konsep pada tema Indahnya Keragaman di Negeriku kelas IV SDN 26 Kendari dengan nilai $t_{\text {hitung }}=2.181>t_{\text {tabel }}$ $=2.021$ dan nilai Sig. (2 tailed) sebesar $0,018<\alpha=0,05$.
\end{abstract}

Kata Kunci: Model problem based learning; pemahaman konsep.

\section{THE EFFECT OF PROBLEM BASED LEARNING LEARNING MODELS ON STUDENTS 'UNDERSTANDING OF STUDENTS' 7 BEAUTIFUL THEMES OF DIVERSITY IN CLASS IV COUNTRY OF SDN 26 KENDARI}

Abstract: This research uses pre-experimental methods with the research design of The Nonequivalent Posttest Control Group Design. The population in this study is all grade IV students of SD Negeri 26 Kendari school year 2018/2019 consisting of two grade IV. A and IV. B. The sample in this study was a grade IV student. A SD Negeri 26 Kendari which numbered 21 students. Data collection techniques are carried out by test, interview and observation methods. Data analysis techniques use descriptive analysis and inference analysis. Based on the results of data analysis and discussion obtained the conclusion that the problem based learning (PBL) model exerts a significant influence on the understanding of concepts on the theme of Beautiful Diversity in Negeriku grade IV SDN 26 Kendari with a value of t_hitung $=2,181>$ t_tabel $=2,021$ and a Sig. (2 tailed) value of $0.018=\alpha=0.05$.

Keywords: Problem based learning Model, concept understanding

\section{Pendahuluan}

Menurut UU No. 20 Tahun 2003 pasal 1, Pendidikan adalah usaha sadar dan terencana untuk mewujudkan suasana belajar dan proses pembelajaran agar peserta didik secara aktif mengembangkan potensi dirinya untuk memiliki kekuatan spiritual keagamaan, pengendalian diri, kepribadian, kecerdasan, akhlak mulia, serta keterampilan yang diperlukan dirinya, masyarakat, bangsa dan negara (Ristekdikti 2016:5).

Pendidikan dalam arti luas berarti suatu proses untuk mengembangkan semua aspek kepribadian manusia, yang mencakup pengetahuan, nilai, sikap dan keterampilannya. Oleh karena itu, dalam pendidikan mencakup kegiatan mendidik, mengajar dan melatih yang dilaksanakan sebagai suatu usaha untuk mentransformasikan nilai-nilai. Dalam pelaksanaannya, ketiga hal tersebut harus berjalan secara terpadu dan berkelanjutan serta serasi dengan perkembangan peserta didik dan lingkungan hidupnya. 
Pembelajaran yang terjadi pada siswa di sekolah dasar adalah guru cenderung kurang melakukan perubahan-perubahan dalam pembelajaran, sehingga pembelajaran siswa cenderung bersifat hapalan dan kurang bermakna bagi siswa. Dalam pembelajaran, guru cenderung menggunakan model pembelajaran langsung yang didominasi oleh model ceramah. Pembelajaran dengan model ceramah menyebabkan pembelajaran menjadi pasif dan membuat siswa menjadi bosan dalam mengikuti pembelajaran. Hal ini menyebabkan pemahaman konsep siswa menjadi kurang optimal

Berdasarkan hasil wawancara pada salah satu guru di sekolah SD Negeri 07 Mandonga tersebut, bahwa pemahaman konsep siswa masih kurang, adapun rendahnya pemahaman konsep siswa dikarenakan model pembelajaran yang dipakai dalam proses pembelajaran kurang sesuai atau kurang berhasil dengan materi yang di ajarkan sehingga kebanyakan siswa kurang aktif atau pasif dalam menjawab pertanyaan dalam materi pembelajaran yang diajarkan. (Sumber: wawancara, guru kelas IV.A SD Negeri 26 kendari, 11 november 2018).

Faktor yang mempengaruhi pemahaman konsep siswa salah satunya yaitu model pembelajaran yang digunakan oleh guru kurang berhasil untuk menggali pemahaman konsep pada diri siswa. Pembelajaran yang dilakukan masih berpusat pada guru bukan siswa. Untuk itu perlu usaha guru agar siswa belajar secara aktif. Salah satu model pembelajaran yang melibatkan aktivitas siswa dalam melakukan penyelidikan terhadap suatu permasalahan adalah model pembelajaran problem based learning. Menurut Ward (dalam Lestari dan Yudhanegara 42:2017) mengemukakan bahwa problem based learning adalah suatu model pembelajaran yang melibatkan siswa untuk menyelesaikan suatu masalah melalui tahap-tahap metode ilmiah sehingga siswa dapat mempelajari pengetahuan yang berhubungan dengan masalah tersebut sekaligus memiliki keterampilan untuk menyelesaikan masalah. Akinoglu dan Tandongan (2007) mengemukakan bahwa pembelajaran model problem based learning secara umum implementasinya mulai dengan tujuan dari model problem based learning, pembentukan kelompok kecil yang terdiri dari 5 atau 7 siswa, pembagian permasalahan yang telah disiapkan, pemecahan masalah, menguji permasalahan, tetapi jika tidak memberikan masalah dapat membuat riset atau praktek.

Menurut Margetson (1997) mengemukakan bahwa pembelajaran membutuhkan jauh lebih besar terintegrasi pengetahuan. Pembelajaran yang menuntut siswa yang aktif dalam melakukan keterampilan ilmiah tentunya membuat interaksi siswa dengan guru maupun siswa dengan siswa akan terjalin dengan efektif. Disini juga siswa dapat melakukan penyelidikan dan menemkan sendiri masalahnya serta siswa juga mempunyai peluang untuk membangun kecakapan hidup serta siswa terbiasa mengatur dirinya sendiri

Berdasarkan uraian diatas, maka penulis tertarik untuk mengangkat judul penelitian yaitu "Pengaruh Penerapan Model Pembelajaran Problem based learning Terhadap Pemahaman Konsep Siswa Pada Tema Indahnya Keragaman Di Negeriku Kelas IV.A SD Negeri 26 Kendari.

\section{Metode Penelitian}

Jenis penelitian yang digunakan yaitu penelitian kuantitatif Menurut Kasiram (2008: 149) dalam bukunya penelitian kualitatif dan kuantitatif mendefinisikan penelitian kuantitatif adalah suatu proses menemukan pengetahuan yang menggunakan data berupa angka sebagai alat menganalisis keterangan mengenai apa yang ingin diketahui. Desain penelitian ini adalah The Nonequivalent Pretest-Posttest Control Group design (Sugiyono 2015:60). Penelitian ini akan dilaksanakan di SD Negeri 26 Kendari, Jln. Imam Bonjol No 82 Kel Alolama, kecamatan Mandonga, Kota Kendari Provinsi Sulawesi Tenggara. Populasi pada penelitian ini adalah seluruh siswa kelas IV SD Negeri 26 Kendari yang 
terdiri dari dua kelas dengan jumlah 43 siswa. Sampel dalam penelitian ini adalah populasi total kelas IV SD Negeri 26 kendari yang terdiri dari dua kelas yaitu kelas IVa berjumlah 21 siswa terdapat 8 laki-laki dan 13 perempuan sebagai kelas kontrol sedangkan kelas IVb berjumlah 22 siswa terdapat 9 laki-laki dan 14 perempuan sebagai kelas eksperimen. Variabel bebas dalam penelitian ini adalah model Problem Based Learning. Sedangkan variabel terikatnya adalah kemampuan pemahaman konsep siswa. Teknik pengumpulan data dalam penelitian ini dilakukan menggunakan teknik pemberian tes instrumen penelitian untuk mengukur pemahaman konsep siswa berbentuk tes. Tes pemahaman konsep yang akan digunakan adalah tes pretest yang bertujuan untuk mendapatkan hasil kemampuan awal siswa sebelum melakukan perlakuan dan tes posttest yang bertujuan untuk mendapatkan hasil setelah melakukan perlakuan. Tes Pretest yang diberikan kepada siswa sebanyak 11 soal dan Tes posttsest yang diberikan kepada siswa sebanyak 11 soal. Untuk mengukur pemahaman konsep siswa, peneliti menggunakan aturan penskoran (skoring). Sebelum instrumen digunakan dalam penelitian ini, diadakan uji coba terlebih dahulu. Uji coba instrumen dilakukan dikelas IV SDN 26 Kendari untuk mengetahui koefisien validitas dan realibilitas sebagai berikut. Data yang dianalisis dalam penelitian adalah data pretest dan posttest kemampuan pemahaman konsep siswa yang dikonversi menjadi nilai N-Gain. (Lestari \&Yudhanegara, 2017:235).

Analisis data yang digunakan pada penelitian ini adalah analisis deskriptif dan analisis inferensial. Analisis deskriptif digunakan untuk melihat nilai rata-rata (mean), minimum, maximum, simpangan baku dan varians. Sedangkan analisis inferensial digunakan menganalisis data melaui uji hipotesis yaitu untuk mengetahui apa ada atau tidak pengaruh sesudah diberikan perlakuan berupa pembelajaran menggunakan model Problem Based Learning terhadap kemampuan pemahaman konsep siswa. Sebelum dilakukan analisis data melalui uji hipotesis maka dilakukan uji prasyarat yakni uji normalitas yaitu untuk mengetahui apakah kedua populasi berdistribusi normal atau tidak dan uji homogenitas yaitu untuk mengetahui apakah kedua populasi memiliki varians yang sama (homogen) atau tidak. Setelah dilakukan uji homogenitas data kemampuan pemahaman konsep pada kedua kelas, maka dilakukan pengujian hipotesis. Untuk mengetahui ada atau tidaknya pengaruh model pembelajaran PBL terhadap kemampuan pemahaman konsep siswa, digunakan independent uji-t. Langkah pengujian dilakukan dengan menggunakan program SPSS versi 20. Jika ditemukan data berdistribusi normal dan varians homogen, maka dilakukan pengujian hipotesis dengan menggunakan statistik uji-t. (Sundayana, 2015:146)

\section{Hasil Penelitian}

\section{Hasil Analisis deskriptif}

Data kuantitatif yang dianalisis pada penelitian ini diperoleh dari hasil pretest dan posttest, sebelum adanya perlakuan dan setelah adanya perlakuan. dalam penerapan model problem based learning untuk di kelas eksperimen dan model pembelajaran konvensional untuk kelas kontrol. Hal ini untuk melihat, perbedaan model pembelajaran problem based learning dan pendekatan saintifik terhadap kemampuan pemahaman konsep siswa. Data yang dianalisis adalah data $N$-Gain pada kemampuan pemahaman konsep siswa kelas IV SD Negeri 26 Kendari.

Data Hasil Kemampuan Pemahaman konsep Siswa Kelas Eksperimen yang Menggunakan Model Pembelajaran Problem Based Learning. 
Tabel 1. Daftar Distribusi Frekuensi dan Klasifikasi Normalized N-Gain Kemampuan Pemahaman konsep pada Kelas Eksperimen.

\begin{tabular}{cccc}
\hline Normalized Gain & Klasifikasi & F & FrekuensiRelatif (\%) \\
\hline$N$-gain $<0.30$ & Rendah & 3 & 13.04 \\
\hline $0.30 \leq N$ - Gain $\leq 0.70$ & Sedang & 14 & 60,86 \\
\hline$N$-Gain $\geq 0.70$ & Tinggi & 6 & 26.08 \\
\hline Jumlah & & $\mathbf{2 3}$ & $\mathbf{1 0 0}$ \\
\hline
\end{tabular}

Berdasarkan tabel 1 diketahui nilai $N$-Gain pada kelas eksperimen klasifikasi yang sedang dan rendah merupakan klasifikasi terbesar yaitu pada interval $\mathrm{N}$-Gain pada 0.30 dengan jumlah siswa 3 orang dan interval $0.30 \leq N$-Gain $\leq 0.70$ dengan jumlah 14 orang. Sedangkan klasifikasi yang tinggi yaitu pada interval $N$ - Gain $>0.70$ dengan jumlah siswa 6 orang. Data hasil kemampuan pemahaman konsep siswa kelas kontrol yang menggunakan model pembelajaran konvensional disajikan pada Tabel 2 berikut.

Tabel 2. Daftar Distribusi Frekuensi dan Klasifikasi Normalzed N-Gain Kemampuan Pemahaman konsep Siswa pada Kelas Kontrol

\begin{tabular}{cccc}
\hline Normalized Gain & Klasifikasi & F & FrekuensiRelatif (\%) \\
\hline$N$-gain $<0.30$ & Rendah & 6 & 27.27 \\
\hline $0.30 \leq N$ - Gain $\leq 0.70$ & Sedang & 13 & 59.09 \\
\hline$N$-Gain $\geq 0.70$ & Tinggi & 3 & 13.63 \\
\hline Jumlah & & $\mathbf{2 2}$ & $\mathbf{1 0 0}$ \\
\hline
\end{tabular}

Berdasarkan tabel 2 diketahui nilai $N$-Gain kelas kontrol klasifikasi yang sedang dan rendah merupakan klasifikasi terbesar yaitu pada interval $N$-Gain pada 0.30 dengan jumlah siswa 6 orang dan interval $0.30 \leq N$-Gain $\leq 0.70$ dengan jumlah 13 orang. Sedangkan klasifikasi yang tinggi yaitu pada interval $N$ - Gain $>0.70$ dengan jumlah siswa 3 orang. Deskriptif peningkatan pemampuan pemahaman konsep siswa kelas eksperimen dan kelas kontrol

Tabel 3. Statistik Deskriptif Peningkatan Kemampuan Pemahaman konsep siswa pada Kelas Eksperimen dan Kelas Kontrol

\begin{tabular}{lccccc}
\hline \multicolumn{1}{c}{ Kelas } & N & Minimum & Maximum & Mean & Std. Deviation \\
\hline Eksperimen & 23 & 0.27 & 1.00 & 0.6174 & 0.17692 \\
\hline Kontrol & 22 & 0.21 & 1.00 & 0.4559 & 0.25254 \\
\hline
\end{tabular}

Valid N (listwise) $\quad 22$

Berdasarkan hasil analisis deskriptif kemampuan pemahaman konsep pada tabel 4.4 di atas, pada kelas eksperimen dengan jumlah data 23 siswa, diperoleh rata-rata $N$-Gain 0,6174 dengan standar deviasi sebesar 0,17692. Pada kelas kontrol dengan jumlah data 22 siswa, diperoleh nilai rata-rata $\mathrm{N}$-Gain sebesar 0,4559 dengan standar deviasi sebesar 0,25254 . Nilai rata-rata $N$-Gain yang diperoleh pada kedua kelompok menunjukkan bahwa 
nilai 0,6174 tersebut mewakili niali $N$-Gain 23 siswa pada kelas eksperimen. Nilai 0,4559 mewakili nilai $N$-Gain 22 siswa pada kelas kontrol. Nilai $N$-Gain minimum di kelas eksperimen yaitu 0.27 dan maksimumnya 1,00. Sedangkan untuk kelas kontrol nilai $N$ Gain minimumnya 0,21 dan nilai maksimumnya 1,00 .

\section{Hasil Analisis Inferensial}

Dalam analisis inferensial, sebelumnya harus melakukan uji prasyarat yakni uji normalitas dan uji homogenitas. Jika data berdistribusi normal dan bersifat homogen maka data tersebut memenuhi prasyarat untuk melangkah dalam melakukan analisis infensial.

\section{a. Uji Normalitas}

berikut.

Analisis uji normalitas data $\mathrm{N}$-gain normalizeddapat disajikan pada tabel 4

Tabel 4. Analisis Statistik Uji Normalitas Data N-Gain Normalized Kemampuan Pemahaman konsep Siswa Kelas Eksperimen dan Kelas Kontrol

\section{One-Sample Kolmogorov-Smirnov Test}

\begin{tabular}{llrr}
\hline & & \multicolumn{1}{c}{ Ekperimen } & \multicolumn{1}{c}{ Kontrol } \\
\hline $\mathrm{N}$ & & 23 & 22 \\
\multirow{2}{*}{ Normal Parameters ${ }^{\mathrm{a}, \mathrm{b}}$} & Mean & 0.4535 & 0.3695 \\
\cline { 2 - 4 } & Std. Deviation & 0.20493 & 0.30809 \\
\hline \multirow{3}{*}{ Most Extreme Differences } & Absolute & 0.111 & 0.220 \\
\cline { 2 - 4 } & Positive & 0.111 & 0.220 \\
\cline { 2 - 4 } & Negative & -0.098 & -0.146 \\
\hline Kolmogorov-Smirnov Z & & 0.531 & 1.033 \\
\hline Asymp. Sig. (2-tailed) & & 0.940 & 0.237 \\
\hline
\end{tabular}

a. Test distribution is Normal.

b. Calculated from data.

Untuk pengambilan keputusan apakah data normal atau tidak maka cukup membaca pada nilai signifikasinya (Asymp. Sig. (2-tailed). Jika signifikasinya kurang dari 0,05 maka kesimpulannya data tidak berdistribusi normal, jika signifikansi lebih dari 0,05 maka data berdistribusi normal (Sundayana,2017: 90).

Pada tabel di atas,dapat diketahui bahwa nilai Asymp. Sig. (2-tailed) untuk kelas eksperimen adalah 0 , 940> $\alpha$ ( dengan $\alpha=0,05$ ), sehingga $\mathrm{H}_{0}$ diterima. Dengan demikian,dapat disimpulkan bahwa sebaran data $N$-Gain kemampuan penalaran matematis siswa pada kelas eksperimen berdistribusi normal. Sedangkan pada kelas kontrol, terlihat bahwa nilai Asymp. Sig. (2-tailed) yakni 0,237> $\alpha=$ (dengan $\alpha=0,05$ ), sehingga $\mathrm{H}_{0}$ diterima. Dapat disimpulkan bahwa $N$-Gain kemampuan penalaran matematis siswa pada kelas kontrol berdistribusi normal.

\section{b. Uji Homogenitas Varians}

Analisis uji homogenitas varians data $\mathrm{N}$-gain kemampuan pemahaman konsep siswa dapat disajikan pada tabel 5 berikut. 
Tabel 5. Hasil Analisis Statistik Uji Homogenitas Data $N$-Gain Kemampuan Pemahaman konsep Siswa pada Kelas Eksperimen dan Kelas Kontrol.

\section{Test of Homogeneity of Variances}

\begin{tabular}{|c|c|c|c|}
\hline Levene Statistic & df1 & df2 & Sig. \\
\hline 2.338 & 1 & 43 & 0.134 \\
\hline
\end{tabular}

Berdasarkan tabel di atas, hasil perhitungan uji homogenitas dengan taraf signifikan $\alpha=0,05$ dapat diketahuhui bahwa nilai signifikansinya $>0,05(0,222>0,05)$, dari hasil analisis di atas dapat disimpukan bahwa varian dua kelompok yakni kelas eksperimen dan kelas kontrol adalah sama, maka hal ini telah memenuhi asumsi persyaratan dasar homogenitas.

\section{Pembahasan}

Berdasarkan hasil analisis penelitian bahwa kemampuan pemahaman konsep siswa pada kelas eksperimen lebih baik dari pada kemampuan pemahaman konsep siswa pada kelas kontrol disebabkan karena pada proses pembelajaran diberikan perlakuan yang berbeda yaitu pada kelas eksperimen menggunakan model Problem Based Learning sedangkan pada kelas kontrol menggunakan model pembelajaran langsung. Hal itu sejalan dengan penelitian Bilgin dkk. (2008), problem based learning dapat membantu siswa dalam mengembangkan komunikasi dan kemampuan bekerjasama dalam menerima informasi dan menggunakannya.

Data kemampuan pemahaman konsep siswa diperoleh melalui tes kemampuan pemahaman konsep. Tes tersebut diberikan kepada siswa kelas eksperimen dan kelas kontrol dalam hal ini kelas IV SD Negeri 26 Kendari.. Pembahasan hasil penelitian ini terdiri atas tiga sesuai dengan rumusan masalah.

1. Gambaran Kemampuan Pemahaman konsep Siswa di Kelas Eksperimen dengan Model Pembelajaran Problem Based Learning pada Kelas IVa SD Negeri 26 Kendari

Berdasarkan hasil analisis deskriptif, diperoleh nilai rata-rata $\mathrm{N}$-Gain sebesar 0,6174 artinya kemampuan pemahaman konsep siswa di kelas eksperimen tergolong sedang dan standar deviasinya yaitu 0,17692 yang menunjukan bahwa besar penyimpangan data dari rata-rata kelas cukup kecil. Hal ini mengiterpretasikan bahwa pembelajaran yang berlangsung merata pada semua siswa. Hal ini memberikan gambaran bahwa ada peningkatan kemampuan pemahaman konsep siswa dengan penerapan model problem based learning (PBL). Sejalan dengan pernyataan Rusman (dalam Maryam \& Jufri, 2015) pembelajaran problem based learning (PBL) merupakan suatu pendekatan pembelajaran yang diawali dengan penyajian masalah yang dirancang dalam konteks yang relevan dengan materi yang akan dipelajari untuk mendorong siswa memperoleh pengetahuan dan pemahaman konsep, mencapai berfikir kritis, memiliki kemandirian belajar, keterampilan berpartisipasi dalam kerja kelompok, dan kemampuan pemecahan masalah.

Hal tersebut terlihat jelas pada saat pembelajaran berlangsung. Dalam pembelajaran dengan model pembelajaran problem based learning, siswa mengerjakan permasalahan-permasalahan yang terdapat dalam LKS yang diberikan peneliti secara berkelompok kemudian dilanjutkan dengan kegiatan diskusi. Kegiatan kelompok, siswa 
secara tidak langsung memiliki keterampilan untuk menyelesaikan masalah secara mandiri. Hal itu sejalan dengan pernyataan Ngalimun (2013:89) PBL adalah suatu model pembelajaran yang melibatkan siswa untuk memecahkan suatu masalah melalui tahaptahap metode ilmiah sehingga siswa dapat mempelajari pengetahuan yang berhubungan dengan masalah tersebut dan sekaligus memiliki keterampilan untuk memecahkan masalah. Dalam model pembelajaran PBL siswa dituntut menyelesaikan masalah yang ada di LKS dan diberi kesempatan untuk saling bekerja sama, berbagi pengetahuan dengan anggota kelompoknya masing-masing. Kegiatan diskusi kelompok dapat memicu siswa yang memiliki pemahaman yang relatif tinggi dapat lebih memantapkan pemahaman dan pemecahan masalahnya, sedangkan siswa yang berkemampuan rendah dapat memperoleh pemahaman yang lebih baik yaitu dari penjelasan teman sebaya. Dengan adanya diskusi kelompok dapat mengurangi kesalahan pemahaman masalah seseorang terhadap suatu masalah.

2. Gambaran Kemampuan Pemahaman konsep Siswa di Kelas Kontrol dengan Model Pembelajaran konvensional pada Kelas IVb SD Negeri 26 Kendari

Berbeda dengan kelas kontrol yang menggunakan model pembelajaran konvensional. kemampuan pemahaman konsep siswa cukup baik meskipun masih ada beberapa siswa yang memiliki penalaran matematis rendah. Setelah selesai pelaksanaan pembelajaran pada akhir pertemuan dilaksanakan tes akhir (posttest), sehingga diperoleh data $N$-Gain yang merupakan selisi antara nilai pretest dan nilai posttest kemampuan penalaran matematis siswa dibagi dengan selisi skor maksimum yang diperoleh siswa dan nilai pretest. Hal itu sejalan dengan pernyataan Ryberg dkk. (2010) menyelesaikan masalah dan menyampaikan hasil di depan kelas membuat siswa lebih memahami materi dari pada sekedar terlibat dalam kerja kelompok dan berdiskusi hanya dengan kelompok sendiri.

Berdasarkan hasil analisis deskriptif, diperoleh nilai rata-rata $\mathrm{N}$-Gain sebesar 0,4669 artinya kemampuan pemahaman konsep siswa di kelas control tergolong cukup meningkat dan standar deviasinya yang menunjukan bahwa besar penyimpangan data dari rata-rata kelas cukup kecil. Hal ini mengiterpretasikan bahwa pembelajaran yang berlangsung merata pada semua siswa yaitu 0,25254 .

Pada pembelajaran menggunakan model pembelajaran konvensional siswa diberikan LKS seperti biasa yang bukan merupakan masalah nyata, selain itu siswa kurang diberikan kesempatan untuk mengkonstruksi sendiri dalam menyelesaikan permasalahan.Kelas kontrol pada umumnya pembelajaran berpusat pada guru sehingga guru lebih banyak berperan dibandingkan siswa itu sendiri. Suasana yang monoton juga dapat mengakibatkan siswa mudah bosan. Akibatnya, hasil kemampuan pemahaman konsep siswa di kelas kontrol lebih rendah dibanding kemampuan pemahaman konsep di kelas eksperimen.

3. Perbedaan Signifikan Terhadap Kemampuan Pemahaman konsep Siswa pada Penggunaan Model Problem Based Learning dan model konvensional di Kelas IV SD Negeri 26 Kendari

Untuk mengetahui perbedaan pengaruh penggunaan model problem based learning dan model pembelajaran konvensional terhadap kemampuan pemahaman konsep siswa, maka dilakukan uji hipotesis untuk mendapatkan rata-rata nilai $N$-Gain kemampuan pemahaman konsep pada kedua kelas dengan menggunakan statistik independent sample test. Dengan terlebih dahulu melakukan uji prasyarat yaitu uji normalitas data kelas eksperimen dan kelas kontrol serta uji homogenitas varians kedua kelompok sampel. 
Kemudian dari hasil analisis inferensial diperoleh data $N$-Gain kelas eksperimen dan kelas kontrol berdistribusi normal dan bersifat homogen, sehingga memenuhi syarat untuk melakukan pengujian hipotesis dengan menggunakan uji statistik uji-t independen sample t-test yang digunakan untuk menguji perbedaan rata-rata dua kelompok data yang independen. Dari pengujian hipotesis tersebut, diperoleh nilai $t_{\text {hitung }}=2.493$ dengan nilai sig. (2- tailed) sebesar 0,017. Karena $t_{\text {hitung }}=2.493>t_{\text {tabel }}=2.021$ dengan nilai signifikansi $0,017<\alpha=0,05$ yang berarti bahwa nilai $t_{\text {hitung }}$ lebih besar dari nilai $t_{\text {tabel }}$ dan nilai sig. (2-tailed) lebih kecil dari signifikansi $\alpha=0,05$ sehingga $H_{0}$ ditolak yang berarti terdapat perbedaan signifikan pada penggunaan model problem based learning dan model pembelajaran konvensional terhadap kemamp pemahaman konsep siswa.

\section{Simpulan}

Berdasarkan hasil penelitian dan pembahasan diperoleh simpulan sebagai berikut:

1. Berdasarkan hasil analisis deskriptif, diperoleh nilai rata-rata $N$-Gain sebesar 0,6174 artinya kemampuan pemahaman konsep siswa di kelas eksperimen tergolong sedang dan standar deviasinya yaitu 0,17692 yang menunjukan bahwa besar penyimpangan data dari rata-rata kelas cukup kecil. Hal ini mengiterpretasikan bahwa pembelajaran yang berlangsung merata pada semua siswa. Hal ini memberikan gambaran bahwa ada peningkatan kemampuan pemahaman konsep siswa dengan penerapan model problem based learning (PBL).

2. Berdasarkan hasil analisis deskriptif, diperoleh nilai rata-rata $N$-Gainsebesar 0,4669 artinya kemampuan pemahaman konsep siswa di kelas control tergolong cukup meningkat dan standar deviasinya yang menunjukan bahwa besar penyimpangan data dari rata-rata kelas cukup kecil. Hal ini mengiterpretasikan bahwa pembelajaran yang berlangsung merata pada semua siswa yaitu 0,25254 .

3. Berdasarkan uji normalitas data dengan menggunakan analisis Nonparametric test-I sample $K-S$ diperoleh untuk data kemampuan pemahaman konsep kelas eksperimen dan kelas kontrol berdistribusi normal. Selanjutnya, berdasarkan uji homogenitas varins data kemampuan penalaran matematis kelas eksperimen dan kelas kontrol menggunakan independent sample $t$ test, diperoleh data kemampuan penalaran matematis kedua kelompok homogeny dari hasil analisis inferensial diperoleh data $\mathrm{N}$ Gain kelas eksperimen dan kelas kontrol berdistribusi normal dan bersifat homogen, sehingga memenuhi syarat untuk melakukan pengujian hipotesis dengan menggunakan uji statistik uji-t independen sample t-test yang digunakan untuk menguji perbedaan rata-rata dua kelompok data yang independen. Dari pengujian hipotesis tersebut, diperoleh nilai $t_{\text {hitung }}=2.493$ dengan nilai sig. ( 2 - tailed) sebesar 0,017 . Karena $t_{\text {hitung }}=2.493>t_{\text {tabel }}=2.021$ dengan nilai signifikansi $0,017<\alpha=0,05$ yang berarti bahwa nilai $t_{\text {hitung }}$ lebih besar dari nilai $t_{\text {tabel }}$ dan nilai sig. (2-tailed) lebih kecil dari signifikansi $\alpha=0,05$ sehingga $H_{0}$ ditolak yang berarti terdapat perbedaan signifikan pada penggunaan model problem based learning dan model pembelajaran konvensional terhadap kemamp pemahaman konsep siswa

\section{Daftar Pustaka}

Akinoglu, O. dan R.O. Tandogan. 2007. The Effect of Problem Based Active Learning of Student's Academic Achievement, Attitude and Concept Learning. Eurasia Journal of Mathemathics, science \& Technology Education, 3 (1): 71-81. 
Bilgin, I., E. Senocak, dan M. Sozbilir. 2008. The Effects Of Problem-Based Learning Instruction On University Students' Performance Of Conceptual And Quantitative Problems In Gas Concepts. Eurasia Journal Of Mathematics, Science \& Technology Education, 5(2), 153-164.

Dwita, Purnama. (2014). Pengaruh Model Problem Based Learning Terhadap Hasil Belajar Siswa Pada Pendidikan Kewarganegaraan Sekolah Dasar.

Lestari, K. E., \& Yudhanegara, M. R. (2017). Penelitian pendidikan matematika (2nd ed.). Margetson, D. (1997). Why is Problem Based Learning a Challenge? .Dalam Band, D \& Falletti, G.I. The Challenge of Problem based learning, 2nd Edition. London: Kogan Page

Ngalimun. (2013). Starategi dan Model Pembelajaran . Banjarmasin: Aswaja Pressindo. Nurwadani, P. (2016). Pendidikan Kewarganegaraan. Jakarta: Direktorat Jendral Pembelajaran dan Kemahasiswaan Kementrian Riset Teknologi dan Pendidikan Tinggi.

Ryberg, T., dkk. 2010. Identifying Difference in Understandings of PBL, Theory and Interactional Interdependencies. International Conference on Networked Learning, 7: 943-951.

Ruminiati, (2007). Pengembangan Pendidikan Kewarganegaraan SD. Jakarta: Direktorat Jendral Pendidikan tinggi Departemen Pendidikan Nasional Jakarta.

Sundayana, R. (2015). Statistika Penelitian Pendidikan. Bandung: alfabeta.

Sawab. (2017). Pengaruh Model pembelajaran problem based learning terhadap hasil belajar siswa kelas IV pada mata pelajaran ilmu pengetahuan sosial di mathala'ul anwarsindang sari lampung selatan.

Sugiyono. (2018). Metode Penelitian Pendidikan (Pendekatan Kuantitatif, Kualitatif, dan $R \& D)$.

Samniah, N. 2016. Kemampuan Memahami Isi Bacaan Siswa Kelas VII MTs Swasta Labibia. Jurnal

Winataputra, U. S. (2008). Pembelajaran PKn di SD. Jakarta: Universitas Terbuka 